\title{
lodine I 131 Monoclonal Antibody F16SIP
}

National Cancer Institute

\section{Source}

National Cancer Institute. Iodine I 131 Monoclonal Antibody F16SIP. NCI Thesaurus.

Code $C 95025$.

A fully human monoclonal antibody (MoAb) against human $\mathrm{A} 1$ domain of tenascin- $\mathrm{C}$, in small immunoprotein (SIP) format conjug ated with iodine 131 with potential antineoplastic activity. Iodine I 131 MoAb F16SIP binds to tenascin-C on the vascular tissues and delivers cytotoxic radiation to the tumors, thereby minimizing systemic radiotoxicity. Tenascin- $\mathrm{C}$ is a glycoprotein of the extracellular matrix, and the large isoform of this matrix protein is expressed and restricted around vascular structures in the tumor stroma of a variety of different tumors. 